\title{
Planning for Food Systems: Community-University Partnerships for Food-Systems Transformation
}

Jennifer Whittaker, Jill K. Clark, Sarah SanGiovannni, and Samina Raja

\begin{abstract}
The United Nations estimates that by 2050 , more than $66 \%$ of the world's population will live in urban areas. In the face of continuing urbanization, how will communities meet the fundamental need for good food? What kinds of public policies, structures, and systems will ensure equitable and just access to food? We argue that urban universities have a responsibility and an extraordinary opportunity to help create equitable community food systems by amplifying community-led planning and policy to strengthen such systems. Drawing on case studies involving the University at Buffalo State University of New York system and its community partners, we describe the ways in which community-university partnerships can leverage policy change to support stronger food systems. We conclude with lessons for such partnerships: the importance of building lasting relationships for policy change, shoring up community capacity, understanding the benefits and burdens for universities and communities, and reimagining universities' responsibilities to their regions.
\end{abstract}

\section{Keywords}

Community-university partnerships, Buffalo, Chautauqua, Urban planning, Regional planning

\section{Introduction}

The United Nations estimates that by 2050 , more than $66 \%$ of the world's population will live in urban areas (United Nations, 2014). This urbanization will be accompanied by extraordinary challenges and opportunities. The impact of urbanization will be especially evident in community food systems, or the soil-to-soil network that enables food to be grown, processed, distributed, and delivered to urban residents. Even today, communities' food systems are failing to keep up with societal needs. Globally, 793 million people were estimated to be chronically undernourished in 2015, with most food insecurity concentrated in developing countries (FAO, IFAD, \& WFP, 2015). The food systems of more industrialized nations are not serving people well, either. Many countries are facing the twin challenges of prevalent food insecurity and a rise in diet-related chronic disease, often concentrated in the same neighborhoods and population groups. In the United States, for example, $14 \%$ of households were estimated to be food insecure in 2014 (Coleman-Jensen, Gregory, \& Singh, 2015). How will communities meet the fundamental need for good food, in the face of continuing urbanization? What kinds of public policies, structures, and systems will ensure equitable and just access to food? Urban universities have the choice to purposefully engage with, react to, or remain apathetic to these questions. 
We argue that urban universities have a responsibility and an extraordinary opportunity to help create equitable community food systems, especially by amplifying community-driven efforts to transform local government planning and policy to strengthen such systems. Such deliberative food-systems planning and policy is a fairly new practice within the profession of urban and regional planning, although local governments have increasingly begun to use planning and policy to shore up food systems (Raja \& Diao, 2016). We define food-systems planning as a set of future-oriented, place-based, and dynamic activities that strengthen a community's food system through the creation and implementation of community plans and policies, which are often but not always recognized or led by local and regional governments (Raja \& Whittaker, Forthcoming). Individuals and organizations engaged in food-systems planning identify the opportunities and challenges within communities' food systems, gather input from stakeholders and deliberate on the best responses to challenges, and facilitate and implement actions to improve the systems. In a well-functioning system, all community residents can be food secure, farmers, food entrepreneurs, and employees can have economically secure livelihoods, and food is produced with environmentally sustainable practices (Raja \& Whittaker, Forthcoming). At its best, food-systems planning and policy processes are rooted in collaborative and diverse partnerships that span the public, civic, and private sectors (Raja, Hoekstra, Delgado, \& Veenhuizen, 2016).

Urban universities can play an important role as partners by harnessing the integrated power of research, education, and civic engagement to shore up communities' food-systems planning and policy processes (Clark et al., 2015). Many urban universities are located, and embedded as anchor institutions, in communities where the fault lines within food systems are most exposed. Indeed, many are stepping up to help rebuild sustainable food systems. A recent study maps the many ways in which universities have begun to engage in the sustainable food-systems movement, through curricula, establishment of on-campus community gardens, farmers' markets, and other activities (Kameshwari Pothukuchi \& Molnar, 2014). Few of these activities, however, explicitly focus on creating, amplifying, or buttressing plans and policies that can create more equitable food systems. We argue that urban universities are well-positioned to help, and responsible for helping rebuild food systems through community-university partnerships focused on food-systems policy and planning. University support for food-systems policy and planning is especially important, because community food advocates and food entrepreneurs have neither the mandate nor the resources to pursue policy change. Moreover, short-sighted policies often constrain community advocates and entrepreneurs seeking to rebuild food systems. For this reason, we argue that universities can play an important role in amplifying and supporting community-led policy processes to create more just food systems.

We draw on the experiences of the University at Buffalo (UB) State University of New York (SUNY) system and its community partners, to describe ways in which community-university partnerships can leverage policy change to support stronger food systems. UB is the largest and most comprehensive research institution within the public SUNY system (The State University of New York), the largest university system in the U.S., and is home to 13 schools and colleges, including SUNY's only School of Architecture and Planning, the locus of the work described in this article. UB enrolls nearly 30,000 students in undergraduate, graduate, and professional programs (University at Buffalo, The State University of New York). Although numerous academic units and faculty at UB are involved in food-related scholarship, teaching, and civic 
engagement, this paper focuses on the community-based food-systems planning and policy efforts of the School of Architecture and Planning.

\section{Engaging in Food-Systems Planning and Policy Through Education}

The planning profession aims to create places where people can lead healthy, full lives (Raja, Born, \& Kozlowski Russell, 2008). Planners shape land use, housing, economic development, community development, and, increasingly, community food systems. Until the early 2000s, similar to the food-blind manner in which planning was practiced, university education for planners neglected concerns about the food system. In 2004, only nine programs in the country were reported to offer a course on food-systems planning (Hammer, 2004). Following recent trends in communities and professional planning, university planning programs are increasingly teaching about food (Greenstein, Jacobson, Coulson, \& Morales, 2015).

In 2013, the authors conducted a survey of the 73 accredited planning programs in the United States, to gauge their offerings for food-systems planning education. The survey was conducted by telephone. Initial phone calls were made to staff members in departmental offices. Depending on the recommendations of departmental staff, follow-up calls were directed to chairs of departments, administrative professionals, planning faculty, or alternative staff members. Each planning program was called up to three times. Fifty-five of the 73 programs responded.

Findings from the 2013 survey suggest a great deal of variation in the extent to which food is being integrated into planning curriculum. Representatives of twenty-two programs (40\%) reported offering graduate-level, stand-alone courses on food-systems planning in the form of seminars, a sharp increase from reports by Hammer (2004). Thirty-three programs (60\%) reported that food is included as a topic in other courses. Finally, a small proportion $(7.27 \%)$ reported offering studio courses, or intensive practicums, on food-systems planning (see Figure 1). The Department of Urban and Regional Planning at UB is one of the few schools in the country that offers stand-alone courses and practicums on food-systems planning, and beginning in 2016-17, the department launched a formal graduate specialization in food-systems planning. At least one other program at Wayne State University integrates research, education, and engagement through its SEED Wayne program, founded and led by a planning faculty member (Pothukuchi, 2012). Several other programs - including the pioneering program at UW-Madison, which was among the earliest to offer coursework in the area-continue to advance food-systems planning education. Despite these promising developments, food-systems planning remains far from mainstream planning education. 


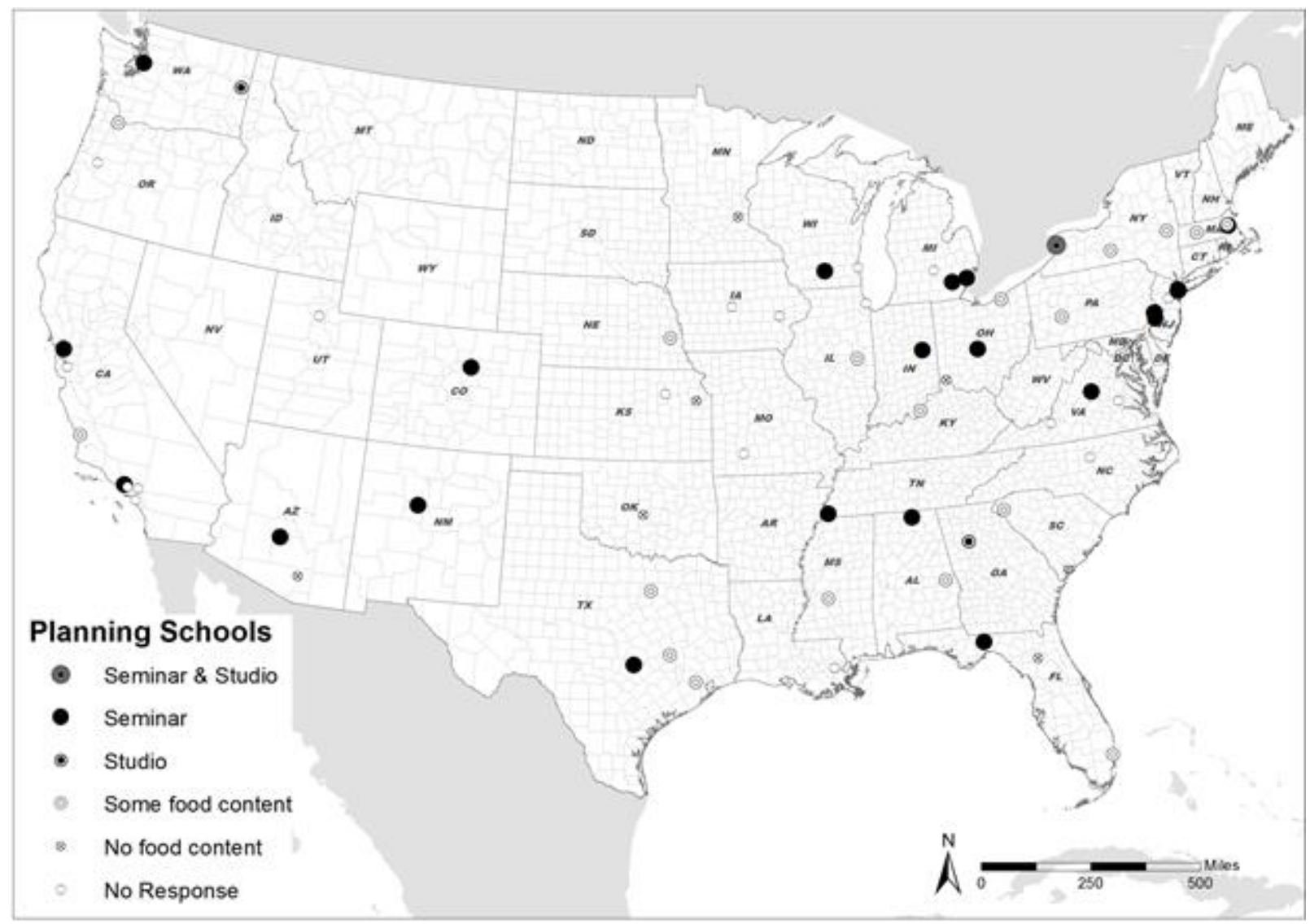

Figure 1. Food-Systems Education Offerings in Accredited Planning Programs.

Universities can play a key role by developing and improving food-systems planning education, especially by offering studios on community food-systems planning/policy change (Mendes \& Nasr, 2011). Planning studios, often required in planning programs, are a longstanding pedagogical tradition in the United States and globally. Typically, in a high-credit-bearing course, students work in a team guided by a faculty instructor to prepare plans (or reports) in response to a real-world community problem (Frank, 2006). Students learn the art of planning through the process of preparing a plan for a community client. A studio is more than an opportunity to blend scientific knowledge (episteme) and technical knowhow (techne); it is an opportunity for students, faculty, and community clients to exercise the Aristotelian idea of phronesis (Flyvberg, 2001), or practical judgment, in response to a community problem.

By co-articulating problems and co-producing knowledge and solutions, students, faculty, and community clients create a dynamic community of practice (Wenger, 1998). For students, a studio is an opportunity to hone their skills as planners in a real-world context. For the faculty member, aside from presenting a rich pedagogical model, the studio is an opportunity to form or deepen relationships in the community. When related to the faculty member's own research area, the studio can also seed lasting action-research partnerships, as illustrated in the case examples below. Importantly, studios can result in research-based plans for community clients. Community partners or clients can use the planning reports to guide future programs, as a basis for grant applications to implement projects, and to advocate for policy change. 


\section{Case Examples of Community-University Partnerships Focused on Planning and Policy for Food Systems}

The cases presented here draw largely on the experiences of the Food Systems Planning and Healthy Communities Lab at the University at Buffalo, whose research focuses on communityled planning and policy to reduce inequities in the food system and to facilitate healthier communities. This interdisciplinary research group, which includes the authors of this article, comprises graduate students, undergraduate students, and researchers working with the principal investigator (PI), a faculty member in the Department of Urban and Regional Planning.

Siemiatycki (2012) describes the multiple roles of planning scholars (and their teams), including: (a) scholar as independent outsider; (b) scholar as public planner; (c) scholar as contractor; (d) scholar as community-based planner; and (e) scholar as activist. Blending these roles, the PI and the lab have a decade-long history of action-based research (Greenwood \& Levin, 2007) on community food-systems planning and policy within the city and surrounding region of Buffalo, New York, and an emerging history of working nationally and globally. We present two case studies, one of Buffalo, New York, and one of Chautauqua County, New York. The varied geographic locus of activities, within UB's urban backyard and in regional rural areas, presents challenges and opportunities, which we explore.

\section{Growing Food Policy in the City of Buffalo, New York}

As a post-industrial Great Lakes city, Buffalo, New York has risen and fallen as a leader in the global food system. During the 19th and early 20th centuries, Buffalo was the number-one grain port in the world, host to mechanized steam-operated grain elevators that moved 300 million bushels of grain each year from the Midwest onto ships that passed through the Erie Canal to markets on the Atlantic seaboard (Raja, Picard, Baek, \& Delgado, 2014). The opening of the St. Lawrence Seaway in 1959 rendered the canal obsolete. Combined with a decline in other large industries, the city faced significant, ongoing economic decline through the end of the 20th century. Today, the city's population is 260,000 , roughly half its former size. With a poverty rate of nearly 30 percent, persistently high unemployment, and a deteriorating neighborhood environment, the city has struggled to rebound.

Simultaneous to the drastic decline in manufacturing, the city lost a key anchor institution. In 1968, UB, the largest public university in New York State, broke ground for their secondary campus in a suburb of the city, an expansion that moved the majority of the university, including sports arenas, cultural events, research centers, and student housing, outside the city (University at Buffalo The State University of New York). As a result, the university's positive economic impact accrued largely outside the urban core. A 2007 study reports that university operations, living expenses of employees and students, and visitors' economic contributions generate about a billion dollars to the region (University at Buffalo Regional Institute, 2007). While suburban areas of the region thrived, the City of Buffalo did not reap similar benefits. Nearly 40 years later, today UB is reconsidering its role in the city by investing in its two city campuses: a downtown medical campus that will host a new medical school and an urban campus in the north of the city. This urban campus will continue to house multiple professional schools, including the 
School of Architecture and Planning, which has a celebrated tradition of working in the City of Buffalo (Biemiller, 2015).

The university has cultivated relationships with community organizations, and these partnerships integrate education, research, and civic engagement activities to strengthen food-systems planning and policy. The UB Food Systems Planning and Healthy Communities Lab collaborates with the Massachusetts Avenue Project (MAP) and Grassroots Gardens of Western New York, two non-profits working to rebuild and strengthen the city's food system. Established in 1992 by a coalition of residents, MAP formally incorporated in 2002. MAP's programs, which are primarily focused on building capacity of city youth, include farm education, youth enterprise development, mobile food markets, and community education and policy outreach. Through this programming, MAP engages and trains about 50 high-school aged youth annually.

Grassroots Gardens Western New York (GGWNY), also established in 1992, enables community-led efforts to enhance quality of life through the creation and maintenance of community gardens. Facilitating a growing, determined network of more than 2,000 community gardening activists tending more than 100 community gardens, GGWNY empowers residents and serves as a channel for strengthening the food system.

Collaboration between the UB Food Lab and these organizations originated in the early 2000s, with conversations between UB faculty and organization staff about their shared passion for rebuilding communities' food systems. The partnerships with these organizations have grown to include mutually reinforcing activities spanning education, research, and community engagement to effect change, including policy change, in Buffalo's food system.

As is common in community-university partnerships focused on food systems (Campbell, 2004), the UB Food Lab's policy work often begins with educational activities to engage university students. The PI of the Food Lab, as part of her university teaching obligation, offers semesterlong intensive planning practicums, also called studios or workshops, during which students prepare a food-systems plan or policy report in partnership with a community client such as a not-for-profit organization or a local government agency. One of the first food-focused planning studios offered by UB was in 2003, during which students prepared Food for Growth, a neighborhood-scale food-system assessment and plan in partnership with MAP (Almeida et al., 2003). The plan, which received regional and national awards from the American Planning Association, documents opportunities and challenges in the food system on Buffalo's west side. Key strengths of Food for Growth are its problem formulation, analyses, and recommendations drawn from the lived experiences of neighborhood residents, experiential knowledge of MAP staff, and academic rigor of the UB team. MAP has since implemented many recommendations from Food for Growth, and the research has helped MAP to "focus its programs and resources in effective ways to address food security and advocate for systemic solutions (Almeida et al., 2003)."

Similar courses at UB have increased students' practical experience in food-systems planning while providing student-generated knowledge to inform local municipal planning and policy. UB's Queen City Garden Plan, resulting from a 2009 graduate course, complemented Food for Growth's emphasis on community engagement by providing a course of action for the City of 
Buffalo's Community Gardens Task Force. Incorporating the results of intensive community visioning sessions, the Queen City Garden Plan assessed the state of Buffalo's community gardens, evaluated legal and regulatory frameworks, and provided a comprehensive community gardening plan. Most important, the goals and objectives established in the community sessions guided the plan (Barton et al., 2009). The report laid the groundwork for several municipal resolutions in support of community gardening in Buffalo.

In Erie County, which is home to the City of Buffalo and additional municipalities, the countywide agriculture preservation plan was informed by Room at the Table (Conley et al., 2011), a food assessment developed during a 2011 planning practicum on behalf of the Erie County Department of Environment and Planning and the American Farmland Trust. Room at the Table provided recommendations to strengthen the food system by rejuvenating the local farming sector while promoting residents' health and fostering economic development. Most recently, Invest in Fresh, developed during a 2013 planning practicum, provided guidance on promoting healthy food retail in small urban and rural areas in collaboration with a rural health network in Chautauqua County, a rural county in the western New York region (Attard et al., 2014). Again, the requirement of participatory community visioning sessions and emphasis on residents' lived experiences helped the studios to identify and propose food policies based on local food-systems practices and experiences.

Just as the UB Food Lab provides education for community members and organizations, the lab and the wider university have benefited from hands-on, community-based education that grounds students and faculty in food-systems planning and policy ideas that are otherwise abstract. This outside-the-classroom experience happens through numerous activities: for more than a dozen years, MAP and GGWNY have generously hosted students from graduate classes; staff members participate as seminar speakers in courses and provide feedback on student work. Purposeful interaction with food organizations' staff inspires and motivates students and embraces a key premise of successful community-university partnerships: everyone has knowledge to teach, and everyone has something to learn (Holland \& Gelmon, 1998).

Although the educational activities described thus far are essential, they alone cannot sustain food-systems policy/planning change. Adoption, implementation, and evaluation of foodsystems policies and plans require a long-term horizon-sometimes more than a decadewhereas educational activities, including intensive studios, tend to last for about a semester. Therefore, educational activities must be supplemented by research and capacity-building partnerships that continually shape, implement, and evaluate local government planning and policy for stronger food systems (Campbell, 2004). In Buffalo, educational activities to support food-systems change are supplemented by participatory action research partnerships (Greenwood \& Levin, 2007).

For example, the UB Food Lab and MAP have partnered on an award-winning participatory action-research project that has lasted for more than 12 years (Raja, Picard, et al., 2014). In addition to guiding and evaluating MAP's programming, the results of this participatory action research generate new scholarship on food-systems planning (Raj, Raja, \& Dukes, 2016; Raja, Breinlich, \& Kallas, 2010; Raja \& Diao, 2016; Raja, Picard, et al., 2014; Raja, Raj, \& Roberts, Forthcoming; Raja \& Whittaker, Forthcoming), form the basis of long-term policy change in the 
city and region (Raja, Hall, et al., 2014), and serve as model for planning practice nationally (Neuner, Kelly, \& Raja, 2011; Raja et al., 2008) and globally (Raja et al., 2016).

To make research accessible and purposeful for policy makers and planners, the UB Food Lab publishes short policy briefs that summarize findings from traditional research articles (Whittaker \& Raja, 2015) and prepares briefs and plans on pressing food-systems issues in Buffalo and the surrounding region. For example, as a member of the Healthy Kids, Healthy Communities-Buffalo (HKHC-Buffalo) coalition, which also includes the local organizations MAP, GGWNY, and public-sector agencies, the UB Food Lab used Buffalo-specific data to develop policy briefs focused on food systems and healthy communities (Delgado, Norton, \& Raja, 2013; Neuner, Gooch, \& Raja, 2012; Neuner, Hall, \& Raja, 2012; Neuner et al., 2011; Neuner \& Raja, 2010a, 2010b).

The university led the research, while community partners selected indicators and participated in data collection, development, layout, and dissemination through trainings. Resolutions and laws that support stronger food systems were developed and adopted based on this collective effort. For example, the work of the HKHC partnership led to the creation of the Buffalo and Erie County Food Policy Council, the second food policy council to be legally recognized in New York State. More recently, a larger coalition that included the university developed a regional sustainability plan, One Region Forward, which includes a section on food (Raja, Hall, et al., 2014). The first regional food plan for Buffalo and surrounding counties (Raja et al., Forthcoming), One Region Forward examines the broader region's responsibility to farmers and rural producers, who are key partners in planning just urban (and rural) food systems.

Urban food-systems policy is most likely to be developed and implemented when it is supported by a diverse, unified, and informed community coalition (Raja, Picard, et al., 2014). Universities are especially well equipped to prepare individuals, via timely training and education, to be policy change agents in their own neighborhoods. In Buffalo, recent examples illustrate this potential. Within the last five years, local and regional government agencies in the Buffalo region launched multiple planning processes, including one to overhaul the city's outdated landuse plan and zoning code, and an effort to develop a regional sustainability plan for a bi-county area; the prior land-use plan, zoning code, and regional plan were largely food blind, with little reference to the community's food system (Raja, Picard, et al., 2014). A coalition of community partners and the university responded to this window of opportunity by training residents, especially youth, to bring food-systems concerns into the planning processes. For example, the UB Food Lab trained city youth working with MAP to design and conduct food assessments to inform planning processes, and these young people conducted extensive neighborhood trainings for residents on zoning and planning. The youths' assessment informs local policies, including the region's first formal plan that includes a focus on food systems (Raja, Hall, et al., 2014).

Collective education and learning can (and should) be extended to a larger community beyond the individuals and organizations directly involved in the immediate community-university partnership. The potential for policy action is amplified when both the university and community co-organize and co-facilitate such outreach into a larger community coalition. For example, the Food Lab, MAP, GGWNY, and other organization jointly hosted two Buffalo Food Policy 
Summits, which included public lectures, seminars, and workshops held in the community and at the university.

Successful university-community partnerships also lay the groundwork for deeper collaboration among other university and community members (Reardon, 2000). In an effort to widen and deepen partnerships on food-justice issues in Buffalo, in 2016 the Food Lab and MAP cofacilitated a workshop that explored strategies by which university-community partnerships can work more effectively. Attendees included pairs of university faculty and their community partners, who discussed problems in the food system as well as challenges and opportunities for addressing these problems by working together. This form of reciprocity creates more sustainable relationships between communities and universities (Bloomgarden, 2013).

Buffalo's experience in using planning to strengthen the food system is premised on a collaborative partnership among community members and researchers at all points in the planning/policy process. Building on Schon's (1984) idea of "problem setting” before problem solving, researchers develop and articulate questions by actively listening to community concerns (Schon, 1984). Community residents play a role in deciding data-collection methods and are trained to gather data. By taking part in the writing of plans, policy briefs, and journal articles, community residents help to translate and disseminate research to wider audiences more effectively. Importantly, community organizations in Buffalo play a key role in holding accountable those involved in food-systems policy work. For example, a group of community organizations recently organized the People's Food Movement, to judge the degree to which formal assessment and planning processes actually reflect residents' aspirations. These collective actions, which are simultaneously formal and informal, civic and political, collaborative and confrontational, ensure that policies, laws, and local government actions intended to strengthen the food system adhere to community visions and are grounded in research.

\section{Growing Food Policy Outside the (Urban) Backyard}

In recent years, the UB Food Lab has begun to engage in supporting food-systems planning across the country via a comprehensive project that seeks to integrate food into urban, regional, and rural planning practices. The Growing Food Connections (GFC) project (growingfoodconnections.org), which partners with Cultivating Healthy Places, The Ohio State University, American Farmland Trust, and the American Planning Association, seeks to build the capacity of local governments that aim to use planning tools to reduce food insecurity among low-resource residents, while improving the viability of small- and medium-sized farms. The project emphasizes integrated knowledge development through three key domains: research, education, and practice. Thus, university partners, professional planning practitioners, and community partners concurrently learn and adapt their practices. Although knowledge generation within this project is iterative across the three domains, here we focus in-depth on one portion of the GFC project - our participatory action policy research - that builds the local governments' and community stakeholders' capacity to use planning and policy to simultaneously improve food and farm security.

The GFC research framework rests on the idea that county governments and municipalities are (and can be) prepared to use planning and policy to address their food system through actions 
unique to their particular geography and community. Indeed, many local governments already actively engage in innovative food-systems planning work, while many others are, with guidance and support, primed for change. In the GFC project, we identify these two types of communities, those actively engaged in food-systems planning and those primed for change, as Communities of Innovation and Communities of Opportunity, respectively. The GFC model (Raja et al., In Press) hypothesizes these two types of communities may be able to learn from each others' experiences, to strengthen their food systems. By providing a domain for joint discussion both within and across communities and then encouraging direct action through practice, the Communities of Innovation and Communities of Opportunity are developing shared repertoires of resources and solutions. Research, capacity-building, and technical support to the local governments of Communities of Opportunity are partially premised on observations, lessons, and challenges happening in Communities of Innovation.

The sharing of lessons learned in our Buffalo and Erie County-based work to facilitate community and university engagement as well as nationwide community-to-community engagement and education has yielded rich knowledge of how universities can partner with communities in distant regions. The cyclical process of learning and sharing, seeking partnerships, building relationships, and increasing capacity has generated the lessons described below.

Currently, the GFC project draws on research on more than a dozen Communities of Innovation (Raja et al., In Press), which were selected, from about 300 communities nationally, for their local governments having played significant planning or policy roles in strengthening small- and medium-sized agriculture and improving food access for low-resource consumers. This knowledge development is transferred, through the participatory research actions described below, to eight new counties identified as Communities of Opportunity. In these counties, a thriving agricultural sector exists alongside high food insecurity (Raja et al., In Press). Communities of Opportunity were selected through rigorous quantitative and qualitative methods to identify the complex notion of a community's opportunity for public policy change. By ranking all 3,141 counties in the United States, based on an aggregated index measuring high potential for food production and high food insecurity, the GFC team selected a subset of counties where increased capacity for policy suggested the most potential for long-term change. In addition to a county's ranking in the index, the selection process included a significant qualitative assessment to understand communities' readiness for engaging in collective action.

Eight counties across the United States were invited to participate as Communities of Opportunity. These are Dougherty, GA; Cumberland, ME; Douglas, NE; Chautauqua, NY; Polk, NC; Wyandotte, KS; and Dona Ana and Luna, both in NM. The eight selected communities represent different census regions of the country and vary along the urban-rural continuum. Because summaries of the in-depth work happening in each community are beyond the scope of this article, we focus on Chautauqua County, NY, a rural county where our depth and duration of experience (about four years) are more limited than in Buffalo. Chautauqua County was selected as a potential Community of Opportunity for its high ranking on the index of agricultural productivity and high food insecurity, in addition to its strong propensity for policy movement and action. The partnership with GFC was finalized when Chautauqua's political leaders committed to addressing food insecurity and farm viability through planning and policy. The 
county's close proximity (approximately an hour southwest of Buffalo) allows further opportunities to develop deeper organic relationships. The UB Food Lab and partners are learning new lessons as we extend our work into a rural, agriculture-based community that displays different challenges and opportunities than those in the City of Buffalo.

Chautauqua County has a vibrant agricultural base enhanced by its location along the shore of Lake Erie, which affords a relatively warm microclimate ideal for fruit production. The county, which includes two small cities and numerous small towns, is home to 1,515 farms, the second highest number in the state of New York. The majority of the county's farms are small- and midsized and face viability challenges resulting from a changing agricultural industry, an increase in principal farm operators, labor shortages, and lack of regional infrastructure to support smallscale diversified production. Food insecurity is high among seniors, minority populations, and low-income families, but strong social stigma toward social safety-net programs has resulted in underutilization of SNAP, TANF, and similarly designed programs. Chautauqua County's government supports the efforts of healthcare organizations, civic organizations, and private enterprises to support and protect their valuable agricultural assets and to provide opportunities to increase food security (Whittaker \& Raja, 2016).

The GFC project is not the first time that UB has worked on food policy in Chautauqua County. Modeled on the UB Food Lab's relationship with the Buffalo-based Massachusetts Avenue Project, an educational component (the planning practicum) served as an initial university investment that laid the groundwork for the UB Food Lab and Chautauqua County organizations to come together. Invest in Fresh, studio work on establishing healthy food retail in Jamestown (completed in 2013 for the Chautauqua County Health Network), provided baseline datacollection and relationship-building opportunities. When Chautauqua County representatives nominated their county to be a GFC Community of Opportunity, the pre-established connection (in addition to their ranking on the index) allowed planning work to proceed at a quicker pace than in other Communities of Opportunity.

The GFC team prepares local governments in Communities of Opportunity to engage in foodsystem policy efforts through capacity-building activities that vary based on pre-existing local government capacity. For example, at the beginning of the project, the team conducted day-long intensive workshops for community representatives at the American Planning Association National Conference. These workshops exposed Community of Opportunity representatives to food-systems planning practices unfolding in other places and provided opportunities for professional development and networking. In addition to providing opportunities for capacitybuilding outside the community, two-day visioning workshops in each community laid the groundwork for the creation of steering committees. Recognizing diverse values and experiences, GFC organized workshops in each location based on principles of equitable civic engagement. These workshops prepared steering-committee members and local government officials to consider how their policy work affects diverse populations. Frequent webinars conducted by food-systems planning practitioners provide learning opportunities across Communities of Innovation and Communities of Opportunity. Such capacity-building opportunities are especially meaningful for governments and organizations with scant resources for food planning. 
Working across multiple communities with varying geographies, resources, and histories presents challenges in integrating teaching, research, and engagement. The different timelines of communities, universities, and funders intensify these challenges. Drawing on our experiences, we share a few lessons.

\section{Challenges and Lessons for Urban Universities' Engagement in Food-Systems Planning and Policy}

Shape the End From the Beginning

Effective engagement in food-systems planning requires relationships that can endure for the time required for the ideation, development, and implementation of food policies and plans. How relationships in the planning process are seeded is crucial to their success and sustainability. As noted, the relationship between the UB Food Lab and community organizations began with conversations among faculty and staff about shared interests in food and community development, and was strengthened through the launch of the first formal food-planning studio. In both Buffalo and Chautauqua County, the studio set the stage for rich, long-term relationships, forming an ongoing community of practice (Wenger, 1998). When communities have limited or no opportunity to partner on a studio, the lab and its partners seek to work when there is an explicit invitation from the community. Without being embedded in or invited by a community, universities have limited ability to support food policy/planning over time. Yet, being outside a community may also allow a university partner to perceive challenges or shortcomings that would be otherwise hidden to an insider.

\section{Build Capacity for Planning Process Before Preparing a Plan}

Cultivating community-university partnerships for food-systems policy change is a timeintensive process that requires a deep, long-term investment to foster trust (Raja, Picard, et al., 2014), particularly if universities' and communities' interests do not always align. Overcoming this misalignment requires robust groundwork, sustained effort, and a focus on mutual benefits (Clark et al., 2015). Universities can help to translate community desire for specific outcomes (e.g., community food security) into a policy agenda. Furthermore, providing the right tools to empower a community to lead a policy and planning process themselves rather than having universities lead processes or agendas for a community, requires the development of skills, capacity, and understanding. Such an undertaking cannot be rushed. To this end, helping communities learn to lead or engage in a planning process, rather than to prepare a plan, may be more crucial in the long run.

Recognize Benefits and Burdens for Communities

For community organizations, working with university partners on food-systems policy is an opportunity to amplify their work. Such partnerships also afford professional development, especially for organizations and individuals from smaller communities. Nonetheless, engaging with universities can be burdensome, and community partners have been exploited in such partnerships (Niewolny et al., 2012). Furthermore, as noted above, community organizations typically do not have a funded mandate to engage in long-term food-policy work. To make the 
most of such a partnership and achieve transformational change, community partners' short-term and long-term missions (e.g., fighting food insecurity) must align with the university partners' policy/planning goals (e.g., policy change for food insecurity) (Kecskes \& Foster, 2013). Additionally, community organizations are a source of local knowledge (Scott, 1998) yet are rarely recognized for their expertise (Niewolny, et al., 2012). To address this problem, the UB Food Lab invites community partners to be co-authors of published works, whenever possible.

\section{Recognize Benefits and Burdens for Universities}

Engaging in planning/policy efforts to shore up food systems is unquestionably rewarding for faculty and students. Universities benefit by having a positive societal impact on the knottiest of problems. Students are inspired by working on issues that matter in communities. Engaging in these planning/policy efforts, however, places a burden on university constituents, especially early-career faculty. Early-career, tenure-track faculty are penalized because engaging in foodsystems planning requires significant time (Mendes et al., 2011). Furthermore, as many earlycareer faculty members have discovered, civic engagement in food-planning processes or development of food-systems plans, with no attendant or subsequent journal publications, is typically not recognized as peer-reviewed scholarship during tenure review. Urban university leaders can help to overcome institutional barriers (Whitmer et al., 2010) by reformulating tenure guidelines that consider the development, passage, and implementation of food-systems policies and plans as civic scholarship. To be sure, these policies must be vetted through peer review in much the same way as traditional scholarship, but failure to recognize the development of foodsystems plan/policies as a valued outcome for early-career faculty will continue to undermine the translation of knowledge for societal good.

Moreover, it is challenging for university faculty to engage in food-systems scholarship and civic engagement because these activities often transcend academic units. Fortunately, the leadership at UB offers significant support, at multiple levels, to support food-systems scholarship, education, and engagement. For instance, in 2015, the university made a multimillion dollar investment to create transdisciplinary university-wide centers, one of which, the Community of Global Health Equity, explicitly supports a focus on food equity globally (University at Buffalo The State University of New York, 2015). Without flexible funding and vision and commitment from university leadership, long-term faculty engagement in food-systems policy and planning is difficult if not impossible.

\section{Reimagine Responsibility in Terms of a Larger Region}

Food systems are rarely contained within an urban or rural area. Urban areas provide markets for rural communities, and rural communities are often sources of food and natural amenities for urban areas. In western New York, for example, stronger food-systems linkages between the City of Buffalo and Chautauqua County could serve to strengthen the region as a whole. The false conceptual divide between urban and rural areas hinders the development of policy ideas that support an integrated regional foodscape. Therefore, food-systems planning efforts require linking with and investing in regions across the rural and urban continuum. Thus far, however, the predominant discourse in food-systems planning and policy draws attention to planning 
innovations in resource-rich urban areas such as Seattle, Portland, and Madison, while overlooking possibilities in rural areas and in small cities (Bedore, 2012).

As anchor institutions, urban universities also reach well beyond the confines of the city boundaries in which they are located. It is well documented, for example, that universities are key actors in their regional economies (Drucker \& Goldstein, 2007). Universities shape the rules and trajectories of regional economic and social outcomes (Gertler, 2010). From a practical standpoint, universities are also key actors in the food system. These institutions purchase food; generate food waste; employ food-system workers; feed students, faculty, and staff; and if they are land-grant universities, they likely have farms in the region. Using the region as a frame for action (Kloppenburg, Hendrickson, \& Stevenson, 1996), urban universities have the ability and, indeed, the responsibility to transcend boundaries. Working across communities, universities can help regional partners to envision just, equitable community food systems, and support regional transformations.

\section{Conclusion}

Planning and policy to strengthen community food systems is a fairly new idea for U.S. communities and their local governments. Many communities, including post-industrial cities and rural areas, often do not have the resources to engage in planning efforts for food systems. These same communities are also home to food-justice organizations that continually wage an uphill battle in the midst of food-blind planning and policy. Urban universities can play a key role in helping to build just food systems, by amplifying efforts to support food-systems plans and policies that strengthen — not undermine - community practices.

\section{References}

Almeida, T., Bostaph, M., Engert, M., Gold, S., Leccese, J., Maisel, J., . . Zlatev, L. (2003). Food for Growth: A Community Food System Plan for Buffalo's West Side. Buffalo, NY: Massachusetts Avenue Project and Department of Urban and Regional Planning, University at Buffalo.

Attard, N., Gordon, T., Jiang, D., Liesten, D., Neal, S., Rogers, D., . . Zhuo, S. (2014). Invest in Fresh: A Plan to Promote Healthy Food Retail in Jamestown, New York. Buffalo, NY: Chautauqua County Health Network and Department of Urban and Regional Planning, University at Buffalo.

Barton, S., Bragg, J., Drag, E., Ganczarz, K., Kistner, J., Ludington, E., . . Watrous, M. (2009). Queen City Gardens Plan: Planning for Community Gardens in the City of Buffalo. Buffalo, NY: Grassroots Gardens of Buffalo and University at Buffalo Department of Urban and Regional Planning.

Bedore, M. (2012). Food system planning in small, buzz-less cities: challenges and opportunities. In A. Vilijoen \& J.S.C. Wiskerke (Eds.), Sustainable food planning: evolving theory and practice (pp. 91-102). Wangeningen: Wangeningen Academic Publishers. 
Biemiller, L. (2015, November 8). Using its city as a teaching lab, a school helps rebuild it, too. The Chronicle of Higher Education. Retrieved from http://chronicle.com/article/Using-Its-Cityas-a-Teaching/234096

Bloomgarden, A. (2013). Reciprocity as sustainability in campus-community partnership. Journal of Public Scholarship in Higher Education, 3, 129-145. Retrieved from http://jpshe.missouristate.edu/205773.htm

Campbell, M. C. (2004). Building a common table: The role for planning in community food systems. Journal of Planning Education and Research, 23, 341-355.

https://doi.org/10.1177/0739456X04264916

Clark, J. K., Kaiser, M. L., Hicks, R., Hoy, C., Rogers, C., \& Spees, C. (2015). Communityuniversity engagement via a boundary object: The case of food mapping in Columbus, Ohio. Journal of Public Scholarship in Higher Education, 5, 126-142. Retrieved from http://jpshe.missouristate.edu/258613.htm

Coleman-Jensen, A., Gregory, C., \& Singh, A. (2015). Household Food Security in the United States in 2013 (Vol. ERR-173). Washington, DC: U.S. Department of Agriculture, Economic Research Service. Retrieved from http://purl.fdlp.gov/GPO/gpo17815

Conley, B., Falk, J., Hawes, T., Hee Jung, Y., Hyoung Kim, G., Maggiotto, T., . . Wright, T. (2011). Room at the Table: Food System Assessment of Erie County. Buffalo, NY: University at Buffalo Department of Urban and Regional Planning.

Delgado, C., Norton, T., \& Raja, S. (2013). Indicators for a Healthy Food and Built Environment in the City of Buffalo. Retrieved from http://foodsystemsplanning.ap.buffalo.edu/wpcontent/uploads/2016/09/40_Delgado_Norton_Raja_2013_Raja(Ed)_IndicatorsforaHealthyFood andBuiltEnvironmentinBuffalo_UB1.pdf

Drucker, J., \& Goldstein, H. (2007). Assessing the regional economic development impacts of universities: A review of current approaches. International Regional Science Review 30(1), 2046. https://doi.org/10.1177/0160017606296731

FAO, IFAD, \& WFP. (2015). The State of Food Insecurity in the World 2015. Retrieved from http://www.fao.org/3/a-i4646e.pdf

Flyvberg, B. (2001). Making Social Science Matter: Why Social Inquiry Fails and How it Can Succeed Again: New York, NY: Cambridge University Press.

Frank, A. I. (2006). Three decades of thought on planning education. Journal of Planning Literature 21(1), 15-67. https://doi.org/10.1177/0885412206288904

Gertler, M. S. (2010). Rules of the game: The place of institutions in regional economic change. Regional Studies 44(1), 1-15. https://doi.org/10.1080/00343400903389979 
Greenstein, R., Jacobson, A., Coulson, M., \& Morales, A. (2015). Innovations in the pedagogy of food system planning. Journal of Planning Education and Research, 35(4), 489-500. https://doi.org/10.1177/0739456X15586628

Greenwood, D. J., \& Levin, M. (2007). Introduction to action research : social research for social change (2nd ed. ed.). Thousand Oaks, CA: Sage Publications.

Hammer, J. (2004). Community food systems and planning curricula. Journal of Planning Education and Research, 23(4), 424-434. https://doi.org/10.1177/0739456X04264907

Holland, B. A., \& Gelmon, S. B. (1998). The State of the "engaged campus": What have we learned about building and sustaining university-community partnerships? Aahe Bulletin, 51(2), 3-6.

Kecskes, K., \& Foster, K. M. (2013). Three questions for community engagement at the crossroads. Journal of Public Scholarship in Higher Education, 3, 7-17.

Kloppenburg, J. J., Hendrickson, J., \& Stevenson, G. W. (1996). Coming into the foodshed. Agriculture and Human Values 13(3), 33-42. https://doi.org/10.1007/BF01538225

Mendes, W., Joe Nasr, J., Beatley, T., Born, B., Bouris, K., Campbell, M. C., . . Wekerle, G. (2011). Preparing future food system planning professionals and scholars: Reflections on teaching experiences. Journal of Agriculture, Food Systems, and Community Development, 2(1), 15-52. http://dx.doi.org/10.5304/jafscd.2011.021.022

Mendes, W., \& Nasr, J. (2011). Preparing future food systems planning professionals and scholars: Reflections on teaching experiences. Journal of Agiculture, Food Systems, and Community Development, 2(1), 15-52. https://doi.org/10.5304/jafscd.2011.021.022

Neuner, K., Gooch, P., \& Raja, S. (2012). Buffalo's Food System: An assessment of current municipal, county, and state policies that regulate Buffalo's food system. Retrieved from http://foodsystemsplanning.ap.buffalo.edu/wpcontent/uploads/2012/08/HKHCpolicybrieflocalBuffalo_FINAL2_27_2012_4.pdf

Neuner, K., Hall, J., \& Raja, S. (2012). Children's Health: A Growing Need to Incorporate Physical Activity into the Daily Lives of Youth. Retrieved from https://drive.google.com/file/d/0B7V7R4q3nicSQ2RaWTRCU31VVTQ/view

Neuner, K., Kelly, S., \& Raja, S. (2011). Planning to Eat: Innovative Local Government Plans and Policies to Build Healthy Food Systems in the United States. Retrieved from http://foodsystemsplanning.ap.buffalo.edu/wp-content/uploads/2012/08/planningtoeat5.pdf

Neuner, K., \& Raja, S. (2010a). Healthy Eating and Active Living: For Children in the City of Buffalo. Retrieved from http://foodsystemsplanning.ap.buffalo.edu/wpcontent/uploads/2012/08/HKHC-Policy-Brief-1_whyhealthyliving.pdf 
Neuner, K., \& Raja, S. (2010b). Strengthening Buffalo's Food System: To Promote Healthy Eating Among Children. Retrieved from http://foodsystemsplanning.ap.buffalo.edu/wpcontent/uploads/2012/08/HKHC-Policy-Brief-2_thefoodsystem.pdf

Niewolny, K. L., Grossman, J. M., Byker, C. J., Helms, J. L., Clark, S. F., Cotton, J. A., \& Jacobsen, K. L. (2012). Sustainable agriculture education and civic engagement: The significance of community-university partnerships in the new agricultural paradigm. Journal of Agriculture, Food Systems, and Community Development, 2(3), 27-42. http://dx.doi.org/10.5304/jafscd.2012.023.005

Pothukuchi, K. (2012). Building sustainable food systems in a single bottom-line context: Lessons from SEED Wayne, Wayne State University Journal of Agriculture, Food Systems, and Community Development, 2(3), 103-119. http://dx.doi.org/10.5304/jafscd.2012.023.011

Pothukuchi, K., \& Molnar, S. A. (2014). Sustainable food systems at urban public universities: A survey of U-21 universities. Journal of Urban Affairs, 37(3), 341-359. https://doi.org/10.1111/juaf.12149

Raj, S., Raja, S., \& Dukes, B. A. (2016). Beneficial but constrained: Role of urban agriculture programs in supporting healthy eating among youth. Journal of Hunger and Envrionmental Nutrition, 1-23. http://dx.doi.org/10.1080/19320248.2015.1128865

Raja, S., Born, B., \& Kozlowski Russell, J. (2008). A Planner's Guide to Community and Regional Food Planning: Transforming Food Environments, Building Healthy Communities. Chicago, IL: American Planning Association.

Raja, S., Breinlich, A., \& Kallas, A. (2010). Partnerships to promote healthy eating in school environments: Lessons from Buffalo, New York. Children, Youth, and Environments, 20(2), 175-189.

Raja, S., \& Diao, C. (2016). Community-led urban agriculture policy making: A view from the United States. Urban Agriculture Magazine, 31, 18-24. Retrieved from http://www.ruaf.org/sites/default/files/UAM\%2031\%20p18-24.pdf

Raja, S., Hall, J., Norton, T., Gooch, P., Raj, S., Hawes, T., \& Whittaker, J. (2014). Growing Together: Ensuring Healthy Food, Viable Farms, and a Properous Buffalo Niagara. Buffalo, NY: Food Systems Planning Healthy Communities Lab.

Raja, S., Hoekstra, F., Delgado, C., \& Veenhuizen, R. (2016). Community involvement in urban planning and policy development to strengthen urban food systems [Editorial]. Urban Agriculture Magazine, 31, 18-24 (Special Issue on Inclusive Use of Urban Space). Retrieved from http://www.ruaf.org/node/4598 
Raja, S., Picard, D., Baek, S., \& Delgado, C. (2014). Rustbelt radicalism: A decade of food systems planning in Buffalo, New York. Journal of Agriculture, Food Systems, and Community Development, 4(4), 173-189. https://doi.org/10.5304/jafscd.2014.044.015

Raja, S., Raj, S., \& Roberts, B. (Forthcoming). The U.S. experience in planning for community food systems: An era of advocacy, awareness, and (some) learning. In A. Blay-Palmer, I.

Knezevic, C. Levkoe, P. Mount, \& E. Nelson (Eds.), Nourishing Communities: Sustainable food system transformation through theory, practice and policy: University of Toronto Press.

Raja, S., \& Whittaker, J. (Forthcoming). Community food infrastructure: A vital consideration for planning healthy communities. In T. Beatley, R. Rainey, \& C. Jones (Eds.), Healthy Environments, Healing Spaces: Current Practice and Future Directions in Health and Design. Charlottesville, VA: University of Virginia Press.

Raja, S., Whittaker, J., Hall, E., Hodgson, K., Khojasteh, M., \& Leccese, J. (In Press). Growing food connections through urban planning: Lessons from the United States. Integrating Food into Urban Planning: Food and Agriculture Organization of the United Nations.

Reardon, K. M. (2000). An Experiential Approach to Creating an Effective CommunityUniversity Partnership: The East St. Louis Action Research Project. Cityscape, 5(1), 59-74.

Schon, D. (1984). The Reflective Practitioner: How Professionals Think in Action. New York, NY: Basic Books.

Scott, J. C. (1998). Seeing like a State: How Certain Schemes to Improve the Human Condition have Failed. New Haven: Yale University Press.

Siemiatycki, M. (2012). The Role of the Planning Scholar. Journal of Planning Education and Research, 32(2), 147-159. doi:10.1177/0739456X12440729

The State University of New York. The State University New York Fast Facts. Retrieved from http://www.suny.edu/about/fast-facts/

United Nations, Department of Economic and Social Affairs, Population Division (2014).

World Urbanization Prospects: The 2014 Revision, Highlights (ST/ESA/SER.A/352). Retrieved from https://esa.un.org/unpd/wup/publications/files/wup2014-highlights.pdf

University at Buffalo Regional Institute. (2007). The Difference a University Makes: An Impact Analysis of the University at Buffalo. Buffalo, NY: School of Architecture and Planning, University at Buffalo.

University at Buffalo The State University of New York. Timeline of UB history. University at Buffalo Archives. Retrieved from http://library.buffalo.edu/archives/ubhistory/timeline.php

University at Buffalo The State University of New York. University at Buffalo Academics. Retrieved from https://www.buffalo.edu/academics.html 
University at Buffalo The State University of New York. (2015). UB Launches Communities of

Excellence. Retrieved from http://www.buffalo.edu/provost/signature-initiatives/communities-ofexcellence.html

Wenger, E. (1998). Communities of Practice: Learning, Meaning, and Identity. New York, NY: Cambridge University Press.

Whitmer, A., Ogden, L., Lawton, J., Sturner, P., Groffman, P. M., Schneider, L., . . Killilea, M. (2010). The engaged university: Providing a platform for research that transforms society. Frontiers in Ecology and the Environment, 8(6), 314-321. https://doi.org/10.1890/090241

Whittaker, J., \& Raja, S. (2015). How food policy emerges: Research suggests community-led practice shapes policy. In S. Raja (Ed.), Translating Research for Policy Series: Growing Food Connections. Buffalo, NY: University at Buffalo.

Whittaker, J., \& Raja, S. (2016). Bridging divides: Opportunities for connecting farmers and underserved consumers in Chautauqua County, New York. In S. Raja (Ed.), Exploring Stories of Opportunity. Buffalo, New York: Growing Food Connections, University at Buffalo.

\section{Author Information}

Jennifer Whittaker is a Research Associate with the Food Systems Planning and Healthy Communities Lab at the University at Buffalo, SUNY. She conducts research on the role of local government policy and planning in facilitating sustainable food systems and healthy communities in rural America, as part of the federally funded Growing Food Connections project. Prior to joining the Food Lab, Jenny served as the Program and Outreach Coordinator for Grassroots Gardens WNY.

Jennifer R. Whittaker

Department of Urban and Regional Planning University at Buffalo

233 A Hayes Hall

Buffalo, NY 14214

E-mail: jrwhitta@buffalo.edu

Telephone: 716-829-5571

Jill K. Clark, Ph.D., is an Assistant Professor in the John Glenn College of Public Affairs at The Ohio State University. Her research focuses on agrifood system policy and practice, centering on community and state governance of food systems, the policy process, and community engagement. She is active in the Ohio Network of Food Policy Councils, the Johns Hopkins Food Policy Network, and the Centre for Sustainable Food Systems. She is also a co-investigator of the Growing Food Connections Project.

Jill K. Clark

John Glenn College of Public Affairs 
The Ohio State University

210N Page Hall

Columbus, $\mathrm{OH}$

E-mail: clark.1099@osu.edu

Telephone: 614-292-2548

Sarah SanGiovanni is a graduate of the Master of Urban Planning program at the University at Buffalo, SUNY, where she also served as a Research Assistant for the Growing Food Connections project in the Food Systems Planning and Healthy Communities Lab. She is currently a doctoral student in Clark University's Graduate School of Geography, where she focuses on the areas of Nature-Society Relations, Urban Geography, and Urban Political Ecology.

Sarah SanGiovannni

The Graduate School of Geography

Clark University

950 Main Street

Worcester, MA, 01610

E-mail: ssangiovanni@ clarku.edu

Telephone: 631-576-6178

Samina Raja, Ph.D., is an Associate Professor of Urban and Regional Planning and an Adjunct Associate Professor of Community Health and Health Behavior at the University at Buffalo, SUNY. Her research, teaching, and civic service focus on the role of planning in building equitable food systems and healthy communities. She is the Principle Investigator at the Food Systems Planning and Healthy Communities Lab and the Principal Investigator of the Growing Food Connections Project.

Samina Raja (Corresponding author)

Department of Urban and Regional Planning

University at Buffalo

233 C Hayes Hall

Buffalo, NY 14214

E-mail: sraja@buffalo.edu

Telephone: 716-829-5881 